\title{
Additional Data and Perspectives on Interspecific Aggression in the Common Loon, Gavia immer
}

\author{
Martin L. Morton ${ }^{1}$ and Maria E. Pereyra ${ }^{1}$ \\ ${ }^{1}$ Department of Biological Sciences, University of Tulsa, Tulsa, Oklahoma 74104 United States; e-mail: marty-morton@ \\ utulsa.edu
}

Morton, Martin L., and Maria E. Pereyra. 2011. Additional data and perspectives on interspecific aggression in the Common Loon, Gavia immer. Canadian Field-Naturalist 125(1): 61-62.

We witnessed the killing of a female Redhead (Aythya Americana) by a male Common Loon (Gavia immer). The wound was delivered into the abdomen from below, and death occurred because of a torn, hemorrhaging liver. This same Common Loon also threatened a female Ring-necked Duck (Aythya collaris) with ducklings. We hypothesize that interspecific aggression by loons might be energetically costly but is sometimes adaptive because it deters predators.

Key Words: Common Loon, Gavia immer, Redhead, Aythya americana, aggression, interspecific fatalities, British Columbia.

Common Loons (Gavia immer) are known for being highly aggressive during the breeding season, and fights between males for territories are often fatal (McIntyre and Barr 1997; Piper et al. 2008). This combative behavior is sometimes directed toward other species as well, especially waterfowl, and, as with conspecifics, can also lead to the death of attacked individuals (Sperry 1987; Kirkham and Johnson 1988). Herein we describe the killing of an adult female Redhead (Aythya americana) and harassment of a Ring-necked Duck (A. collaris) brood by a male Common Loon on a lake in northern British Columbia and discuss possible reasons for this kind of behavior.

Our observations took place from a small bluff on the western shore of an elongate, unnamed lake, without islands, about $2 \mathrm{~km}$ in length and 40 ha in size. The lake is fed and drained by Fourth of July Creek and lies within a glaciated canyon about $28 \mathrm{~km}$ northeast of Atlin, British Columbia, at $59^{\circ} 47^{\prime} \mathrm{N}, 133^{\circ} 28^{\prime} \mathrm{W}$. The site is located next to the northeastern end of Steamboat Mountain (not to be confused with the more well-known Steamboat Mountain west of Fort Nelson).

Since 1998, we have stopped our vehicle on this bluff, where the lake is about $200 \mathrm{~m}$ wide, a few times each summer to watch waterbirds, usually ducks and gulls totaling a dozen or more in number, floating or swimming within easy view. When we arrived at 14:30 on 24 June 2010, however, the lake's surface seemed devoid of waterbirds. This was the first time we had ever seen the lake without waterbirds. After a few minutes, though, we began hearing a male Common Loon making tremolo calls about $200 \mathrm{~m}$ up the lake (north) from us. This was the also the first time we have heard a male making this call. Using $10 \times 40$ binoculars, we were able to locate the loon and were watching when it rose up and made a wing-flapping display. About 15 minutes later, three Redheads, a male and two females, flew in from the north and landed about $80 \mathrm{~m}$ across the water from us. We shifted to observing them as they slowly swam southward into a light wind $(\sim 15 \mathrm{~km} / \mathrm{hr})$ and began to separate, with one female lagging $10 \mathrm{~m}$ or so behind the other two ducks. By chance, we were both focused on the lagging female when the water suddenly erupted beneath her, and the Common Loon emerged to full height with the duck grasped in his bill. During the next 3-5 seconds, using feet and wings, he maintained this erect posture at the surface as he shook the duck violently from side to side. He then dropped her and she began flapping and kicking before righting herself to face her attacker with neck extended and head held low to the water in what we took to be a threatening or defensive posture. Meanwhile, the loon watched her intently from a distance of 3-4 m but did not move toward her or touch her again. After a couple of minutes, the female's head began to droop and as it became submerged she rolled over completely once, again flapping and kicking, then became motionless with head underwater. She was dead. The loon watched for about 5 min more as the body drifted with the wind then swam over to a position about $30 \mathrm{~m}$ from the eastern shore. The other two Redheads had flown off when the attack began and we did not see them again.

Eventually the female's body drifted ashore, enabling us to recover it and to perform an autopsy. Only a small spot of blood was visible on the ventral plumage, but once the skin was removed a ragged hole $1-2 \mathrm{~cm}$ in diameter in the abdominal wall $1 \mathrm{~cm}$ distal to the tip of the sternum was revealed. Within the abdomen, we found large blood clots which obviously came from the liver because it was torn into pieces whereas the other internal organs were undamaged.

We returned to the same viewing site at 14:50 on 15 July. A male Common Loon, which we assumed to be the same individual as we had observed on 24 June, was present and very close to where we had last seen him over near the eastern shore, and once again there were no other birds on the water. This changed shortly, when a female Ring-necked Duck emerged from marshy shoreline vegetation about $40 \mathrm{~m}$ from the loon and, trailed by five young about one-third grown, began swimming northward along the water's edge. When a dead, recumbent tree was encountered they did not swim out and around it; rather, they clambered through 
the branches or beneath them and remained close to the shoreline. All the while, the loon was facing them and watching. He then dipped his head underwater for a few seconds, then lifted it up and dove. The hen immediately turned toward the shore, only a meter or so away, and, along with her brood, swam with wings flapping to it then ran up and across a grassy area into a thicket of willows. Seconds later the loon surfaced where they had been, but did not follow onto the land. During the additional 20 minutes that we watched, he moved very little and the ducks did not reappear. We did not notice any female Common Loons during either of our visits, but there was about $150 \mathrm{~m}$ of shoreline marsh where the duckling-loon interaction occurred that may have been suitable habitat for loon nesting.

The majority of recorded attacks by loons on waterfowl have involved harassment and sometimes killing of ducklings and goslings (Sperry 1987; Kirkham and Johnson 1988). The body size, strength, and bill shape of loons makes them dangerous to even larger individuals, as shown by two records of fatal attacks on adult Canada Geese (Branta canadensis) that were defending nests, one by an Arctic Loon (G. arctica; Jones and Obbard 1970) and another by a Common Loon (Sperry 1987). Although puncture wounds, possibly attributable to loons, have been found in dead floating ducks (Munro 1939), there are only a few eyewitness accounts of fatal attacks by loons on adult waterfowl. We suggest that this is because adult waterfowl are quite aware that loons are dangerous and are usually careful to avoid them. In the fatal encounter we witnessed, however, the Common Loon was able to approach from behind and below the Redhead without her detecting it.

Ultimate explanations for fighting behavior among conspecifics so intense that severe injury or death may occur usually invoke the importance of future reproductive success (Enquist and Leimar 1990; Kemp 2006). More difficult to understand is why such a high level of aggression by male loons is also aimed at heterospecifics. At least four explanations have been advanced. These involve predation for food, competition for food, sexual selection, and non-discriminatory attacks devoid of fitness benefit. But loons do not eat the waterfowl they kill, overlapping use of food resources seldom occurs, and females do not appear to observe fighting males. By default, this leaves the tentative conclusion that loon attacks on waterfowl are examples of aberrant or non-adaptive behavior (Kirkham and Johnson 1988). As pointed out by Sperry (1987), however, encounters between loons and other waterbirds may be more frequent than is commonly recognized, especially on small lakes. Our observations support this hypothesis because our small lake was apparently swept free of gulls and ducks by a resident male Common Loon, and he attacked at once when any reappeared.

We assume that a significant expenditure of time and energy is required for such intense patrolling activity, which occurs even through the night (Paruk 2008), and that this activity may not be an example of misdirected territorial behavior, as described by Murray (1971). We propose instead that, unlike many passerine birds (Veen et al. 2000; Fitzsimons 2006), loons do not innately discriminate among territorial intruders as to their depredation potential. Still, in some circumstances, their willingness to attack all intruders might prevent a predation event — an adaptive outcome. For example, small islands are often used as nesting sites by Common Loons, probably because this decreases exposure to mammalian predators (McIntyre 1994; McIntyre and Barr 1997). Nevertheless, island and floating nests are sometimes depredated (McIntyre and Mathisen 1977). This means of course that any mammal involved must swim to and from the island and, while in the water, expose itself to attack by a guarding male loon.

\section{Literature Cited}

Enquist, M., and O. Leimar. 1990. The evolution of fatal fighting. Animal Behaviour 39: 1-9.

Fitzsimons, J. A. 2006. Anti-predator aggression in the Common Myna Acridotheres tristis. Australian Field Ornithology 23: 202-205.

Jones, R. N., and M. Obbard. 1970. Canada Goose killed by Arctic Loon and subsequent pairing of its mate. Auk 87: 370-371.

Kemp, D. J. 2006. Ageing, reproductive value, and the evolution of lifetime fighting behaviour. Biological Journal of the Linnean Society 88: 565-578.

Kirkham, I. R., and S. R. Johnson. 1988. Interspecific aggression in loons. Journal of Field Ornithology 59: 3-6.

McIntyre, J. W. 1994. Loons in freshwater lakes. Hydrobiologia 279/280: 393-413.

McIntyre, J. W., and J. F. Barr. 1997. Common Loon (Gavia immer). In The Birds of North America, Number 313. Edited by A. Pool and F. Gill. The Academy of Natural Sciences, Philadelphia, Pennsylvania, and the American Ornithologists' Union, Washington, D.C.

McIntyre, J. W., and J. E. Mathisen. 1977. Artificial islands as nest sites for Common Loons. Journal of Wildlife Management 41: 317-319.

Munro, J. A. 1939. The relation of loons, Holboell's grebes, and coots to duck populations. Journal of Wildlife Management 3: 339-344.

Murray, B. G., Jr. 1971. The ecological consequences of interspecific territorial behavior in birds. Ecology 52: 414423.

Paruk, J. D. 2008. Nocturnal behavior of the Common Loon, Gavia immer. Canadian Field-Naturalist 122: 70-72.

Piper, W. H., C. Walcott, J. N. Mager, and F. J. Spilker. 2008. Fatal battles in common loons: a preliminary analysis. Animal Behaviour 75: 1109-1115.

Sperry, M. L. 1987. Common Loon attacks on waterfowl. Journal of Field Ornithology 58: 201-205.

Veen, T., D. S. Richardson, K. Blaskmeer, and J. Komdeur. 2000. Experimental evidence for innate predator recognition in the Seychelles warbler. Proceedings of the Royal Society of London B 267: 2253-2258.

Received 23 April 2010

Accepted 15 Sept 2010 